\title{
The motivations and expectations of students pursuing maritime education
}

\author{
Yui-yip Lau • Adolf K.Y. Ng
}

Received: 24 June 2014 / Accepted: 9 January 2015 / Published online: 27 January 2015

(C) World Maritime University 2015

\begin{abstract}
The ever-changing global environment has increased emphasis on the research and creation of knowledge dedicated to professional practice. The maritime industry serves as the illustrative example, of which it has transformed from a traditionally largely unskilled, labor-intensive industry to a capital-intensive, sophisticated one. This has transformed the nature of maritime education from a highly practical, hands-on approach to tertiary education emphasizing on business and analytical skills, as characterized by the increasing number of tertiary institutions offering under- and postgraduate maritime programs. However, the motivations and expectations of students pursuing such programs have remained under-researched. In this study, we have conducted a questionnaire survey towards under- and postgraduate students who pursue maritime programs. The aim is to understand their profiles, motivations, and expectations of respective programs that these students have enrolled in. Constructive recommendations and strategies are provided to contribute to an effective planning and management of program articulation.
\end{abstract}

Keywords Maritime education · Maritime programs · Tertiary institutions ·

Undergraduate $\cdot$ Postgraduate

\section{Introduction}

The maritime industry is one of the four economic pillars of Hong Kong. According to a summary statistics on the Hong Kong shipping industry (Transport and Housing

Y.-y. Lau

Hong Kong Community College, The Hong Kong Polytechnic University, Hong Kong, China

\section{A. K. Ng}

Department of Supply Chain Management, I.H. Asper School of Business, University of Manitoba, Winnipeg, MB, Canada 
Bureau 2012), Hong Kong is currently among the world's top 10 fleet owning countries/territories. There are a total of 72,524,000 tonnages for all registered vessels in Hong Kong, while the number of vessels is 2035 and the number of authorized ship insurers in Hong Kong has reached 90. The maritime industry has made significant economic contributions to the city. For instance, ship agents and managers and local representative offices of overseas shipping companies have generated a profit of HKD 5,975 million, while the profit made by ship owners or operators of sea-going vessels was HKD 93,727 million. The Hong Kong maritime industry has created a wide range of industry groups and job opportunities: 7,653 persons engaged in ship agents and managers and local representative offices of overseas shipping companies business; 4,461 persons joined the workforce in ship owners or operators of sea-going vessels; 2,024 persons were involved in ship owners and operators of Hong Kong-Pearl River Delta Vessels; and 285 persons were employed as shipbrokers.

To maintain the competitiveness of Hong Kong's maritime industry in the world, it would be essential to maintain a comprehensive maritime education. However, there has been increasing concerns that maritime studies may gradually "fade out" under an integration of courses covering broader themes to be redundant. ${ }^{1}$ As the changing global environment has created an emphasis on dedicated knowledge, professional, and research (Moreby 2004), employees of the highest caliber should respond effectively to ongoing changes and professional education could be an effective and direct way to improve productivity (Becker 1993). In recent years, there has been a substantial growth in "professional" and "practice-based" programs based has taken place among academic institutions (Bourner et al. 2001), which emphasize apprentice-style, nonacademic learning approaches.

The maritime industry serves as an illustrative example, especially after its transformation from a largely unskilled labour- to a capital-intensive industry, and contributed to the presence of tertiary education in maritime studies (Grammenos 2002; Heaver 2002; Levinson 2006; Stopford 2009). Many governments formulate policies to train up officers on sea-going vessels and shipping firms ashore through maritime education. Mitropoulos, the secretary-general of the International Maritime Organization (IMO) believed that an extensive international education and training would be essential to continually upgrade knowledge and skills throughout one's working life ${ }^{2}$. In the early years, maritime education mainly focused on vocational training of deck and electronic officers on board sea-going vessels as their knowledge, skills and willingness could contribute to the reliability and efficiency of shipping operations (Gardner et al. 2007; Harlaftis and Theotokas 2004; Theotokas 2007). However, factors such as economic growth, the rise in multimodal supply chains, technological revolution and sophisticated maritime business models have called for the need to redesign the curriculum of maritime education with an objective to appeal to the younger generation. There is also

\footnotetext{
${ }^{1}$ Here, it is interesting to recall a plenary session held during the Annual Conference of the International Association of Maritime Economists (IAME) 2000 (Naples, Italy), discussing this issue in light of the restructuring of Cardiff University, UK, and the integration of the then Department of Maritime Studies and International Transport to the University's Business School. During the conference, some scholars expressed the view that the end of maritime studies higher education degrees was probable.

${ }^{2}$ This is an opening address by Efthimios E. Mitropoulos, E. Secretary-General of the International Maritime Organization on 10 May 2006 for the Maritime Safety Committee (MSC), 81st session.
} 
a need for maritime programs to adopt a wider strategic view, as opposed to a narrow, operational view (Mangan et al. 2001).

In this paper, we understand maritime education as an interdisciplinary academic field that embraces ship management, humankind's critical monolithic skills, and knowledge for being management trainees in companies and deck cadets on board. To meet the ever-rising national and international standards within the maritime industry, such as Port State Control (PSC) and the International Ship and Port Facility Security (ISPS) Code, maritime education should enhance, and explain, integration between human activities and the condition of the maritime environments (Fu et al. 2010; Lewarn 2002; Zhu 2006). To align maritime programs with the needs of maritime stakeholders, their curriculums should inscribe business and management skills, e.g., language, decision making, leadership, organizational knowledge, interpersonal, etc., into consideration. Indeed, they should equip students with the desired skills and proper knowledge and professional attitudes for the maritime industry. Although the demands for both under- and postgraduate maritime studies programs keep on growing rapidly, the reasons for such demand remain rather unclear. To fill in this gap, we review the development of maritime education and examine the value of under- and postgraduate maritime programs from the student's perspective, with a special focus on Hong Kong. It aims to explore whether exiting maritime education is an effective way for occupational groups to achieving their professional status and in what ways education supports a substantial growth of maritime industry and generates increasing productivity and equips industrial practitioners with desired skills.

The rest of the paper is structured as follows. Section 2 presents the situation of maritime education in Hong Kong, followed by an explanation of the methodology in Section 3. Section 4 discusses the empirical results. Before the concluding remarks in Section 6, Section 5 examines the structures and characteristics of the demands for under- and postgraduate maritime programs in Hong Kong.

\section{Maritime education in Hong Kong}

The Hong Kong Special Administrative Region (HKSAR) Government strongly supports the education and trainings of programs in the maritime industry (The 2013 Policy Address 2013; Hong Kong Maritime Department 2013). A number of local academic institutions offer programs related to maritime studies at both post- and undergraduate levels. Table 1 illustrates some major maritime programs offered by Hong Kong's tertiary and professional institutions.

\subsection{Scope of area}

The majority of training courses and educational programs associated with maritime studies focus on transportation, logistics operations and supply chain development. Hong Kong is among the world's top 10 fleet owning countries/territories, and a port of Hong Kong is one of top 5 ports in the world, handling 23 
Table 1 The major maritime programs in Hong Kong

\begin{tabular}{|c|c|}
\hline Institution & Program \\
\hline CUHK & Master of laws (maritime and transportation law) \\
\hline HKMA & Professional diploma in shipping and logistics management \\
\hline $\begin{array}{l}\text { HKPC, HKLA, HKEA and HKST } \\
\text { LA }\end{array}$ & Professional diploma programme in logistics and shipping operations \\
\hline HKPU & BBA (Hons) in international shipping and transport logistics \\
\hline HKPU & MSc in international shipping and transport logistics \\
\hline HKPU & Post-graduate diploma in international shipping and transport logistics \\
\hline HKPU & Higher diploma in international shipping and transport logistics \\
\hline HKSU & Certificate for proficiency in survival craft and rescue boats \\
\hline HKSU & Certificate for advanced fire-fighting training \\
\hline HKSU & Certificate for proficiency in medical first aid \\
\hline HKSU & Certificate for radar observation and plotting and radar stimulator \\
\hline HKSU & Certificate for arpa stimulator \\
\hline HKSU & Certificate for medical care on board \\
\hline MSTI & Higher diploma in maritime studies \\
\hline MSTI & 23-week Junior general purpose rating course \\
\hline SCOPE & Continuing education certificate (CEC) in sea transport \\
\hline SCOPE & $\begin{array}{l}\text { Continuing education diploma (CED) in shipping and logistics man- } \\
\text { agement }\end{array}$ \\
\hline SPACE and HKSC & Advanced certificate in shipping and logistics \\
\hline SPACE and HKSTLA & Certificate in business logistics (sea transport and logistics) \\
\hline
\end{tabular}

CUHK, City University of Hong Kong, HKEA Hong Kong Exporters' Association, HKLA Hong Kong Logistics Association, HKMA Hong Kong Management Association, HKPC Hong Kong Productivity Council, HKPU The Hong Kong Polytechnic University, HKSTLA Hong Kong Sea Transport and Logistics Association, HKSC Hong Kong Shippers' Council, HKSU Hong Kong Seamen's Union, MSTI Maritime Services Training Institute, SCOPE School of Continuing and Professional Education of the City University of Hong Kong, SPACE School of Professional and Continuing Education of the University of Hong Kong. Source: Various universities and institutions

million twenty-foot equivalent units (TEUs) (UNCTAD 2012). These evidences suggest that it would be necessary for Hong Kong to develop maritime education programs that focus on sea freight management and operations.

\subsection{Course design}

Considerable current maritime programs emphasize on shipping operations, dangerous goods handling, import/export trading practices, port and terminal operations, intermodal transport operations, and chartering practice. When designing new programs, it is important to balance theoretical and practical knowledge.

Over the years, considerable research works have contributed to the literature regarding maritime education and training, the skills required for maritime employees, and the structure of maritime courses (e.g., Barnett et al. 2006; Carp 2004; Cooper et al. 
2003; Emad and Roth 2008; Evangelista and Morvillo 1998; Gardner et al. 2007; Hara 2000; Ircha 2006; Lewarn 2002; Ng et al. 2011; Paine-Clemes 2006; Pettit et al. 2005; Ruan 2002; Sampson 2004; Shah et al. 2007). Taussik (1998) highlights interdisciplinary training and education in maritime industry as being critical for the maritime stakeholders. Barnett et al. (2006) identify seafarer requirements at sea and shore-based maritime sectors have contributed to these initiatives through mapping the multiple career opportunities and maritime education that exist for seafarers. Finally, Shah et al. (2007) outlines a specific template for postgraduate level courses requiring a fine balance between academic and vocational relevance in maritime education.

Nevertheless, research examining the significance of different incentives in decisions to embark on maritime education has remained rather scarce. The extents by which actual features of such programs correspond to the aspirations of the enrolled under- and postgraduate students have not been empirically studied. Many previous studies also seem to share some methodological shortcomings. First, many do not have applied research methodologies, e.g., statistical, experimental, etc., and conclusions are often based on theoretical discussions. Many are merely extensive analyses about regulations in the maritime industry and the changing needs of contemporary business environment. Inadequate attention has been paid to students, the direct users of educational services. Also, although there are some studies which attempt to address this deficiency (e.g., Ng et al., 2009; 2011), comprehensive studies comparing under- and postgraduate students have been found wanting. Understanding such, in this study, we conduct a questionnaire survey with students enrolling in under- or a postgraduate maritime programs. Specifically, we focus on the following issues:

- Students' profiles

- Their considerations, motivations, and channels of information before choosing to study on maritime programs

- Their expectations, particularly in academic knowledge, career, and personal development

- Their selection of career paths after graduation

- Their evaluations of the features of maritime programs.

We compare the survey findings between under- and postgraduate students through a comprehensive database developed to a survey within a same maritime education institution. The study explores the process of professionalization within a shipping world and offer useful insights and advice to improve existing underand postgraduate maritime programs so as to sustain the development of such programs in the long run.

\section{Methodology}

A questionnaire based on the Likert-style score scale ( $1=$ strongly agree; $2=$ agree; 3 =fairly agree; 4 =fairly disagree; $5=$ disagree; and $6=$ strongly disagree) was designed, and distributed to students who have enrolled in under- and postgraduate programs in 
maritime studies. During the fall of 2011, 250 questionnaires were distributed to 180 undergraduates and 70 postgraduates studying maritime programs at the Department of Logistics and Maritime Studies (LMS) at the Hong Kong Polytechnic University (HKPU), pursuing the Bachelor of Business Administration in International Shipping and Transport Logistics and the Master of Science in International Shipping and Transport Logistics, respectively. We have decided to focus on HKPU because it has been offering education for vocational training of deck officers and electronic officers on board sea-going vessels for potential managers to ship management for decades, and is considered to be a very significant player in Hong Kong's maritime education. Since the 2000s, LMS (Department of Logistics, or LGT, before 2008) has re-designed the curricula of all maritime programs by incorporating subjects related to management and general business issues within a maritime industry rather than highly specialized or technical subjects, e.g., marine engineering, maritime law, maritime technology, etc. To ensure that the respondents could provide relevant answers based on real learning experience, all of them have completed at least one year of studies in their respective programs. $^{3}$

The response rate was encouraging-76.4\% with 191 completed questionnaires (with valid responses). The questionnaire was divided into two sections: In Section A, participants were asked to provide background information related to their work experiences and studies, for instance, their highest academic qualification, years of working experience within a maritime industry, nationality, age, family background, etc. In Section B, participants provided detailed information about their studies including higher education enrolment, employment, and scholarships during their studies as well as their plans and preferred work after graduation. The questionnaire also asked respondents on the following topics: (1) issues considered when deciding to pursue their maritime programs, (2) information channels for their current maritime programs, and (3) a description of their maritime programs. The questions were asked in the form of statements and participants responded by choosing the extent to which they agree with a particular statement or not (i.e., eight to nine statements per theme).

To comply with confidentiality, data analysis was undertaken collectively without reference to any particular survey participants or institutions. Additionally, the survey questions and certain information in Section 5 were based on some semi-formal discussions with a number of relevant parties or materials pertaining to scholars, industrial practitioners, and maritime journalists. All aspects of the attributes could be validated in the questionnaire and addressed the study objectives (Malhorta and Grover 1998).

To ensure statistical sensibility of the collected data, we have conducted a series of $t$ tests to evaluate their reliability and addressed potential non-response bias on the results (Armstrong and Overton 1977). The non-response bias was measured by dividing the 191 survey respondents into two groups (Table 2), and we used this as the database for further analysis. The results revealed that the collected data was statistically significant at the $5 \%$ significance level.

\footnotetext{
${ }^{3}$ When the survey was undertaken, most undergraduate programs run by the universities in Hong Kong, including HKPU, were still under the 3-year system. Hence, all the survey respondents were either in their second year or, in the case of undergraduate students, third year of study.
} 
Table 2 Detailed information of survey participants

\begin{tabular}{lcccr}
\hline Student category & Male & Female & Frequency & Percent \\
\hline Undergraduates & 63 & 85 & 148 & 77.5 \\
Postgraduates & 21 & 22 & 43 & 22.5 \\
Total & 84 & 107 & 191 & 100.0 \\
\hline
\end{tabular}

\section{Empirical results}

\subsection{Background Information}

Most undergraduate students enrolled in undergraduate maritime programs have completed secondary education for at least two years, or have obtained higher diploma or associate degree, and have articulated to programs that they are currently pursuing through the Non-Joint University Programs Admissions System (Non-JUPAS) ${ }^{4}$. Simultaneously, over $90 \%$ of the postgraduate students consist of degree holders in business, management, and/or marine engineering. Their degrees are awarded by universities worldwide, including the University of Hong Kong (Hong Kong), the Chinese University of Hong Kong (Hong Kong), the Hong Kong Polytechnic University (Hong Kong), City University of Hong Kong (Hong Kong), Shanghai Maritime University (China), Shanghai International Studies University (China), Dalian Maritime University (China), Southwest Jiaotong University (China), University of Applied Sciences (Germany), University of Santiago de Compostela (Spain), Rouen Business School (France), Huddersfield University (UK), and Curtin University of Technology (Australia). The rest of the respondents have obtained other professional qualifications with solid work experience in the shipping, transport, or logistics sectors before proceeding to their postgraduate maritime programs. In Hong Kong, there is less restriction in language, since in most cases English is used as the main medium of instruction. Additionally, there are non-Chinese students enrolled in such programs every year as exchange students to take part in maritime programs.

Broadly speaking, only 7.4 and $9.3 \%$ of the under- and postgraduate students, respectively, have family members who have worked in the shipping industry, or in any maritime-related employment before (Table 3). Among them, two have a (former) marine engineer within the families - a senior safety officer and a captain. Although the results suggest that few under- and postgraduate students enrolled in maritime programs had family members working in a maritime industry, 75.6 and $65.1 \%$ of under- and postgraduate students, respectively, found that a role of maritime tradition was significant to their decision to enroll in maritime programs. Not surprisingly, 83.8 and $70 \%$ of under- and postgraduate students, respectively, reported that an economy of their hometowns are currently associated with jobs related to a maritime industry.

\footnotetext{
${ }^{4}$ JUPAS is the main route of application designed to assist students with Hong Kong Diploma of Secondary Education (HKDSE) Examination results (past and/or current) to apply for admission to programmes offered by the JUPAS-participating tertiary institutions in Hong Kong.
} 
Table 3 Family members with work experience related to the maritime industries

\begin{tabular}{llll}
\hline Student category & Answer & Frequency & Percent \\
\hline Undergraduates & Yes & 11 & 7.4 \\
& No & 137 & 92.6 \\
Postgraduates & Yes & 4 & 9.3 \\
& No & 39 & 90.7 \\
Under-and postgraduates & Yes & 15 & 7.9 \\
& No & 176 & 92.1 \\
Total & & 191 & 100.0 \\
\hline
\end{tabular}

The results indicated that $27 \%$ of the undergraduate students held at least one university degree or possessed postgraduate qualifications, while $16.3 \%$ of their mothers were also university degree holders. For postgraduate students, $27.9 \%$ of their fathers and $14 \%$ of their mothers were degree holders (Table 4). Nevertheless, none of the parents of the under- or postgraduate students have attended any marine academies.

The results indicate that the annual family income of our respondents stands at a lower and of the scale (Table 5). Over $60 \%$ of undergraduate students reported that their families earned less than HKD 203,410 (equivalent to about USD 26,245 in August 2014) per year, and only about $20 \%$ and $10 \%$ of these families can be categorized as middle- and upper-income class, respectively. Therefore, it is not surprising to find that $44.6 \%$ of the undergraduate students have part-time works so as to relieve some financial difficulties. Similarly, $58.1 \%$ of the postgraduate students reported that their respective family income was at lower income levels and that $30.2 \%$ of them have a full time job (Table 6).

\subsection{Professional experiences before and during enrolment}

Interestingly, no postgraduate students in our survey had any professional sea-going experience, although 13 possessed some onshore experiences, such as sales and marketing, accounting, law, documentation, customer services, procurement, to name but a few. As expected, most undergraduate students did not have any professional maritime experiences when they enrolled in their maritime programs (Table 7), although some of them had some professional experiences: 56.5 and $83.3 \%$ had worked in non-maritimerelated part- and full-time jobs, respectively. In addition, over $70 \%$ of the undergraduate students planned to work part time during their studies. This was not only due to financial incentives but also a desire to gain some professional experiences before graduation. Meanwhile, professional experiences and financial incentives were the main factors that prompted postgraduate students to pursue their current studies (Table 8).

\subsection{Plans after graduation}

Over half of the undergraduate students who completed the survey planned to continue their postgraduate education in maritime studies after graduation, and this could foster 


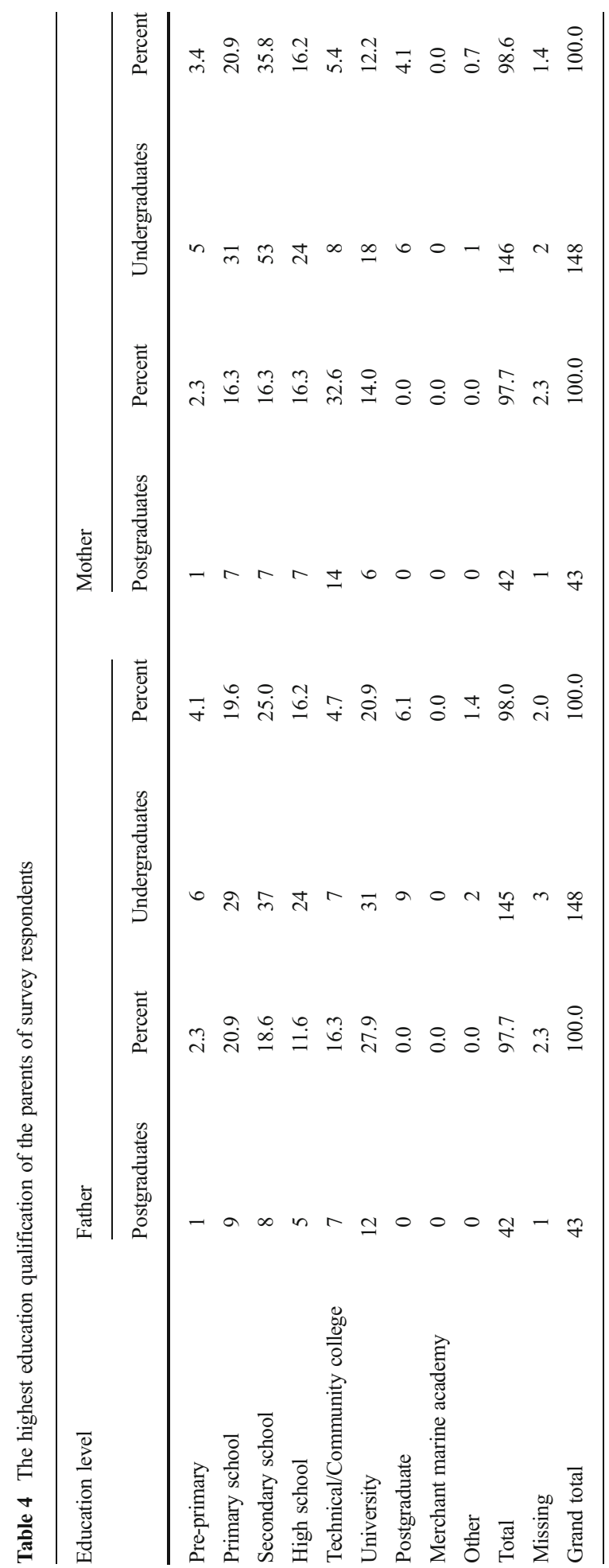


Table 5 Annual income of the family members of survey respondents

\begin{tabular}{|c|c|c|c|c|c|c|}
\hline \multirow[t]{2}{*}{ Income range } & \multicolumn{2}{|c|}{ Under- and postgraduates } & \multicolumn{2}{|c|}{ Undergraduates } & \multicolumn{2}{|c|}{ Postgraduates } \\
\hline & Frequency & Percent & Frequency & Percent & Frequency & Percent \\
\hline$<122,040 \$$ & 58 & 30.4 & 41 & 27.7 & 17 & 39.5 \\
\hline $122,050-203,400 \$$ & 56 & 29.3 & 48 & 32.4 & 8 & 18.6 \\
\hline $203,410-457,650 \$$ & 32 & 16.8 & 26 & 17.6 & 6 & 14.0 \\
\hline $457,660-762,750 \$$ & 7 & 3.7 & 6 & 4.1 & 1 & 2.3 \\
\hline$>762,750 \$$ & 16 & 8.4 & 10 & 6.8 & 6 & 14.0 \\
\hline Missing & 22 & 11.4 & 17 & 11.4 & 5 & 11.6 \\
\hline Total & 191 & 100.0 & 148 & 100.0 & 43 & 100.0 \\
\hline
\end{tabular}

themselves to obtain higher educational qualifications in a maritime field (Table 9). Except for coast guards and the shipbuilding industry, the responses for all other sectors were similar and showed positive feedbacks. Indeed, the undergraduate students often planned to seek professional life from other industries.

In terms of plans after graduation, the responses from postgraduate students are significantly different from their undergraduate counterparts. Few of them consider pursuing further studies, neither in logistics and maritime theme $(9.3 \%)$ nor in another discipline $(4.7 \%)$. Half of them indicate that they prefer finding a job in the maritime (and, in some cases, logistics) industries. There was also a tendency to seek professional life from other industries among these postgraduate students, especially in the banking and financial sectors. Slightly over half of them wanted to work in a shipbuilding industry (56\%), closely followed by the (general) transport industry (53\%). Port and coast guards are jointly ranked as the third most preferred option (49\%). Finally, tourism is ranked as the fifth most preferred option $(40 \%)$. Based on the collected data, postgraduate students least prefer to work in public administration (21\%) (Table 10).

Table 11 presents the results of postgraduate students' responses to the question "if maritime industries are an ideal work to be associated with, then which subsector?" The results show that about $45 \%$ of them showed an interest in containers, $14 \%$ in dry bulk, and $11.6 \%$ in tankers. Only few would like to work for cruise or coastal shipping.

Table 6 Current job of survey respondents

\begin{tabular}{|c|c|c|c|c|c|c|c|}
\hline \multirow[t]{2}{*}{ Category } & \multicolumn{2}{|l|}{ No } & \multicolumn{2}{|c|}{ Yes (part time) } & \multicolumn{2}{|c|}{ Yes (full time) } & \multirow[t]{2}{*}{ Total } \\
\hline & Frequency & Percent & Frequency & Percent & Frequency & Percent & \\
\hline Undergraduates & 82 & 55.4 & 66 & 44.6 & 0 & 0.0 & 148 \\
\hline Postgraduates & 27 & 62.8 & 3 & 7.0 & 13 & 30.2 & 43 \\
\hline Under- and postgraduates & 109 & 57.1 & 69 & 52.4 & 13 & 6.8 & 191 \\
\hline
\end{tabular}


Table 7 Professional experience of survey respondents

\begin{tabular}{|c|c|c|c|c|c|c|c|}
\hline \multirow[t]{2}{*}{ Category } & \multicolumn{2}{|l|}{ No } & \multicolumn{2}{|c|}{ Yes (part time) } & \multicolumn{2}{|c|}{ Yes (full time) } & \multirow[t]{2}{*}{ Total } \\
\hline & Frequency & Percent & Frequency & Percent & Frequency & Percent & \\
\hline Undergraduates & 107 & 72.3 & 23 & 15.5 & 18 & 12.2 & 148 \\
\hline Postgraduates & 15 & 34.9 & 8 & 18.6 & 20 & 46.5 & 43 \\
\hline Under- and postgraduates & 122 & 63.9 & 31 & 16.2 & 38 & 19.9 & 191 \\
\hline
\end{tabular}

4.4 Motivation to enroll in maritime programs

Nearly $40 \%$ of the family members of the students being surveyed expressed a positive view towards maritime studies, and this suggests that their family members are likely to support them to pursue such programs and develop a career path in the maritime industry. With the support from their family members, $30 \%$ of the undergraduate students reported state that the maritime programs that they are pursuing were their first choice during their university admission application. In contrast with undergraduate students, four out of five postgraduate students decided to pursue maritime programs. Practical and occupational-orientated nature seems to be the most crucial factor for pursuing maritime programs at postgraduate level (Table 12).

Forty-three postgraduate students have answered the question about scholarships in pursuing maritime program. Thirteen and four postgraduate students have received scholarships from tertiary institutions and external parties, respectively. In our data analysis, this is a crucial point of postgraduate students pursuing in such program.

\subsection{Issues considered in enrolling a maritime program}

To explore the key issues considered by under- and postgraduates when enrolling in a maritime program, the questions asked and a description of the summarized mean scores are presented in Tables 13 and 14, respectively. The results indicate that the top 3 issues considered by undergraduate students when pursuing a maritime program are (1) to enhance knowledge about a logistics industry, (2) to enhance knowledge about maritime industry, and (3) program's accreditation by professional units with the last item scoring the best mean score. The findings also show that undergraduate students pay less attention to (1) higher chance of getting a job, (2) great interests in the courses,

Table 8 Major reasons of postgraduates for taking up employment during study

\begin{tabular}{lcr}
\hline Factor & Frequency & Percent \\
\hline Program's requirement & 1 & 2.3 \\
Self-interests & 3 & 7.0 \\
Gain work experience & 8 & 18.6 \\
Financial incentives & 9 & 20.9 \\
Other reasons & 1 & 2.3 \\
Missing & 21 & 48.8 \\
Total & 43 & 100.0 \\
\hline
\end{tabular}


Table 9 The sectors that undergraduates prefer their ideal work to be associated

\begin{tabular}{lcc}
\hline Sectors & Frequency & Percent \\
\hline Maritime industry & 96 & 64 \\
Port industry & 94 & 63 \\
Transport industry & 99 & 66 \\
Public administration & 102 & 68 \\
Sea tourism industry & 87 & 58 \\
Coast guard & 56 & 37 \\
Shipbuilding industry & 61 & 41 \\
Banks/financial sector & 92 & 62 \\
Other industries & 78 & 52 \\
Do not know yet & 53 & 35 \\
\hline
\end{tabular}

(3) to be associated with their respective countries' maritime tradition, and (4) no other alternatives. On the contrary, postgraduate students emphasize the following factors: (1) a reputation of the programs/departments, (2) university/faculty/departments have good networks within the industry, and (3) the easiness to obtain good grades in courses, followed by (4) courses are practice-oriented, which is in line with a crucial feature of the maritime programs (as mentioned earlier). Interestingly, when considering whether to enroll in a particular maritime program or not, postgraduate students are generally not affected by family members, friends, or colleagues whose have already pursued such programs.

\subsection{Information channels for the maritime programs}

In this section, we address the ways on how respondents found out about the program they enrolled in (Table 15). In this regard, it is surprising to see that, while social network (notably family members, friends, teachers, or knowing a third person) is not an effective channel for undergraduate students to gather information about maritime programs, it is very important for postgraduate students. In fact, a large number of enrolments

Table 10 The sectors that postgraduates prefer their ideal work to be associated

\begin{tabular}{lcc}
\hline Sectors & Frequency & Percent \\
\hline Maritime industry & 22 & 51 \\
Port industry & 21 & 49 \\
Transport industry & 23 & 53 \\
Public administration & 9 & 21 \\
Sea tourism industry & 17 & 40 \\
Coast guard & 21 & 49 \\
Shipbuilding industry & 24 & 56 \\
Banks/financial sector & 31 & 72 \\
Other industries & 2 & 5 \\
Do not know yet & 0 & 0 \\
Total & 170 & 396.0 \\
\hline
\end{tabular}


Table 11 For postgraduates, if 'Maritime industries' is the ideal work to be associated with, then which sub-sector?

\begin{tabular}{lrr}
\hline Factors & Frequency & Percent \\
\hline Containers & 19 & 44.2 \\
Tankers & 5 & 11.6 \\
Dry bulk & 6 & 14.0 \\
Cruise & 1 & 2.3 \\
Coastal shipping & 1 & 2.3 \\
Other & 2 & 4.7 \\
Missing & 9 & 20.9 \\
Total & 43 & 100.0 \\
\hline
\end{tabular}

(especially postgraduate students) were not a direct result of any aggressive marketing campaigns. The advancement of information technology has also helped students to seek relevant course information without time and place restrictions, and because of this, both under- and postgraduate students mostly agree that information technology is an important channel to obtain necessary information regarding the programs.

\subsection{Description of the maritime programs}

During the survey, we have invited survey respondents to describe their enrolled maritime programs. The received answers are summarized in Table 16. Most under- and postgraduate students agreed that the maritime program outcomes meet their initial expectations. The workload is appropriate, and the teaching staff has adopted various teaching methods to allow students to learn effectively. In general, all responses to the specific questions fell within a range of strongly agree (1) to rather agree (3). None of the 191 survey respondents has expressed any disagreement towards any of the statements in this section. However, despite the well-qualified teaching staff, many feel that the courses are too academic or theoretical and that the courses could, and should, cover more practical aspects of the maritime industry. Unlike their postgraduate counterparts, undergraduate students appreciate the fact that they can enhance their professional competence and skills and transfer job-related skills from the maritime programs. However, $54 \%$ of them reported that they had limited or no knowledge about the Chinese maritime industry (Table 17). Given the closer ties between Hong Kong and other parts of China, this suggested a major shortfall of the maritime programs being studied.

Table 12 The crucial feature of postgraduate maritime program

\begin{tabular}{lcr}
\hline Factors & Frequency & Percent \\
\hline Accredited by a professional unit & 12 & 28.0 \\
Practice/occupational-orientated & 28 & 65.1 \\
Relatively lower academic entrance & 1 & 2.3 \\
$\quad$ requirements & 1 & 2.3 \\
Other & 1 & 2.3 \\
Missing & 43 & 100.0 \\
Total & & \\
\hline
\end{tabular}


Table 13 Issues considered in enrolling the program by undergraduates

Factors

Enhance knowledge about the logistics industry

Enhance knowledge about maritime industry

Program's accreditation by professional units

1.99

High quality of supporting facilities of the institution

High reputation of program/department

High quality of teaching staff

City where the department is located

Higher chance getting a job

Great interests in the courses

Want to be associated with my country's maritime tradition

No alternatives

\section{Discussions}

We have closely examined the profiles, motivation, and expectations of under- and postgraduate students pursuing maritime related programs. In addition, we have analyzed the structures and characteristics of the demands for such programs.

Table 14 Issues considered in enrolling the program by postgraduates

Factors

Mean score

High reputation of program/department

University/faculty/department has good networks within the industries

1.98

Easy to obtain good grades in courses

Courses are practice-orientated

High quality of teaching staff

Higher chance getting a job

Great interests in the courses

Enhance knowledge about the logistics and maritime industry

High quality of supporting facilities of the institution

Program's accreditation by professional units

Smooth graduation

Successfully admitted to the program with academic performance

Want to be associated with my country's tradition

Chances to secure scholarships or financial supports

Affordable program's tuition fee

Higher earnings in maritime/logistics industries than others

Friends or family encouraged me to enroll in the program

Friends or colleagues also enrolled in the program 
Table 15 Sources of information-undergraduates and postgraduates

\begin{tabular}{lll}
\hline Factors & $\begin{array}{l}\text { Mean score } \\
\text { (undergraduates) }\end{array}$ & $\begin{array}{l}\text { Mean score } \\
\text { (postgraduates) }\end{array}$ \\
\hline Friends & 3.51 & 2.91 \\
Recommended by former teachers & 3.56 & 2.86 \\
Someone who know enrolled the program before & 3.65 & 2.84 \\
$\begin{array}{l}\text { Family member is a student/graduate of this institution/ } \\
\quad \text { university }\end{array}$ & 4.47 & 4.33 \\
$\begin{array}{l}\text { Learnt this program from university exhibition } \\
\text { Learn this program from mass media }\end{array}$ & 3.36 & 3.53 \\
$\begin{array}{l}\text { Suggested by professions in the logistics and maritime } \\
\quad \text { industries }\end{array}$ & 3.70 & 3.14 \\
$\begin{array}{l}\text { Intentionally searched for related information on the } \\
\quad \text { program }\end{array}$ & 2.94 & 2.62 \\
\hline
\end{tabular}

Our study discusses the presence of a triple maritime dimension: Students select to pursue an undergraduate maritime degree, and that they may consider studying for a maritime postgraduate program, and finally their ambition is to work in the maritime sector. In general, the motivation of both under- and postgraduate students in pursuing their respective maritime programs is strategically driven by practical considerations. The results support the notion that their maritime programs generally meet the initial expectations of both under- and postgraduate students.

Regarding the degree choice considerations, according to our findings, a good program should possess the following competencies: (1) increases students' professional competence and skills, (2) provides updated information on the industry, and (3)

Table 16 Description of maritime programs by under- and postgraduates

\begin{tabular}{lll}
\hline Factors & $\begin{array}{l}\text { Mean score } \\
\text { (undergraduates) }\end{array}$ & $\begin{array}{l}\text { Mean score } \\
\text { (postgraduates) }\end{array}$ \\
\hline Courses are too academic/theoretical & 2.07 & 2.16 \\
Course are too practically oriented & 2.93 & 2.88 \\
Workload is too heavy or cramped & 2.66 & 2.81 \\
$\begin{array}{l}\text { Increases students' professional competence and } \\
\quad \text { skills }\end{array}$ & 1.81 & 1.95 \\
$\begin{array}{l}\text { Provision of updated information } \\
\text { Students built up networks with people within }\end{array} \quad 2.58$ & 2.19 \\
$\quad$ industries & 2.08 & 2.17 \\
Courses are taught by well-qualified teaching staff & 1.99 & 2.12 \\
Teaches industries-related academic theories to stu- & 1.92 & 1.95 \\
$\quad$ dents & & 2.29 \\
Transmit job-related skills to students & 2.18 & 2.07 \\
Variation of teaching methods & 2.29 & 1.95 \\
Program outcome fits with my initial expectation & 2.20 & \\
\hline
\end{tabular}


Table 17 Level of knowledge on Chinese maritime industry — undergraduates

\begin{tabular}{|c|c|c|c|c|c|c|c|c|c|}
\hline \multicolumn{2}{|c|}{ Very informed } & \multicolumn{2}{|l|}{ Informed } & \multicolumn{2}{|c|}{ Rather informed } & \multicolumn{2}{|l|}{ Not at all } & \multicolumn{2}{|l|}{ Missing } \\
\hline Frequency & Percent & Frequency & Percent & Frequency & Percent & Frequency & Percent & Frequency & Percent \\
\hline 3 & 2.0 & 63 & 42.6 & 60 & 40.5 & 20 & 13.5 & 2 & 1.4 \\
\hline
\end{tabular}

courses to be delivered by well-qualified teachers. Additionally, well-qualified teaching staff should provide a wide variety of innovative teaching methods so as to transfer relevant professional and practical skills to students and enhance their knowledge about the maritime industry.

Both under- and postgraduate students perceive the maritime programs they pursue as being too theoretical. To address this problem, we strongly believe that tertiary institutions should put more efforts in strengthening their networks with a local maritime industry. In return, the latter should offer more training opportunities, mentorship, and internship placements, so as to allow students to establish or expand their industrial networks more effectively. For example, HKPU has often invited scholars from foreign universities to conduct reviews and help in redesigning maritime programs. Other parties from the maritime industry, including industrial associations, potential and current employers, and alumni were also invited to offer advices to the programs, and to better equip students when they entered the job market. Furthermore, our findings illustrate that a large number of students pursue maritime programs because of an appropriate study workload, and that in some cases students perceive that they could obtain good results rather easily. The long-term impacts of such trend against the quality of the maritime industry professionals are subject to further research.

Unsurprisingly, most students expect to work in the maritime industry after graduation. For postgraduate students, a container sector is their ideal work under the maritime industry. This should not be deemed surprising, given that most of the world's traded cargoes are carried by container shipping both in terms of value and tonnages $(\mathrm{Ng}$ and Liu 2014), and thus, it often receives the most attention, in both media and the maritime programs themselves. This suggests that maritime programs should perhaps pay more attention to the non-container aspects. Furthermore, with closer economic ties between Hong Kong and other parts of China in recent years, the maritime and logistics development of both regions are likely to affect each other significantly. However, our findings suggest that not many undergraduate students have even fundamental knowledge about the Chinese maritime industry. Thus, in the future, universities and tertiary institutions in Hong Kong should consider incorporating subjects with more "Greater Chinese elements" into both under- and postgraduate curricula of maritime education in future and invite more reputable guest speakers to deliver seminars or presentations about the Chinese maritime industry.

Regarding survey respondents' family background, few family members of the surveyed under- and postgraduates have worked in the shipping industry or in maritimerelated activities. This suggests that an influence from family members probably does not play a vital role in providing first hand or updated relevant maritime programs information in Hong Kong. Compared with undergraduate students, most postgraduate students are already working in the maritime industry and their key contact parties (notably, 
colleagues, supervisors, former teachers, and associations) can provide them with useful information regarding the maritime programs, and share past experience with them in pursuing such programs. Support from these parties often creates peer-group influences that motivate these students to pursue the maritime programs. Finally, our findings suggest that information technology has become a necessity for students to access maritime program information in real time.

Regarding the annual family income of the respondents, most under- and postgraduate students come from or are living at low-income levels, and they take up employment during their studies because of financial necessities. Only $39.5 \%$ of the postgraduate students have been awarded scholarships from tertiary institutions/universities and/or external parties. Based on these findings, the HKSAR Government and industrial associations should take more initiatives in offering scholarships to motivate qualified students to enroll in maritime programs.

\section{Conclusions}

Quality education is fundamental for the long-term well-being of the maritime industry. As a global maritime logistics hub, maritime education has been growing in Hong Kong in the past decade as reflected by an increasing number of enrolments in maritime programs and the number of programs offered to under- and postgraduates by local tertiary institutions.

In this study, we collected data from 191 students (148 undergraduates and 43 postgraduates) through a questionnaire survey. By doing so, we can understand more about the students' profiles, their sources of information, motivation, and expectations of the associated programs that they have enrolled in. In addition, we explored the different perceptions and evaluations of undergraduates and of their enrolled programs. This study has examined a professionalization process of the maritime industry and provides invaluable insight to researchers, maritime industries, associations, perspective students, and current ones. By studying the characteristics and structures of the demands for maritime programs, strategies and recommendations are made to contribute to an effective planning and management of maritime program articulation, and to help Hong Kong to develop into a world-class maritime educational hub in Asia-Pacific and the world. Useful strategic advice for developing a global maritime logistics hub is also given for others' reference. In the past, Hong Kong's maritime education focused on seafarer vocational training and covering narrow and highly technical aspects in shipping. Nowadays, they do not only cover shipping-dedicated subjects (e.g., navigation and communication systems, shipping logistics, ship-broking, chartering practice, marine navigation and meteorology, port planning and management, etc.) but also core (e.g., business finance, introduction to business law, global economic environment, operations management, etc.) and non-core business subjects (e.g., business English, transferrable skills, etc.). In many cases, the restructured maritime programs have incorporated a wide range of theoretical and commercial knowledge and skills, so as to equip graduates with both specialized knowledge in shipping and logistics as well as strong management competency, such as leadership, teamwork, communication, and problemsolving skills.

A well-structured and comprehensive maritime program offers both width and depth (from certificate and doctorate level) to train up students in business 
knowledge and analytical skills. A number of local [e.g., Hong Kong Council for Accreditation of Academic and Vocational Qualifications (HKCAAVQ) ${ }^{5}$ and overseas [e.g., National/Scottish Vocational Qualification (N/SVQ) ${ }^{6}$, Association of MBAs (AMBA) ${ }^{7}$, the Association for the Advancement of Collegiate Schools of Business (AACSB) ${ }^{8}$, and the European Foundation for Management Development-European Quality Improvement System (EFMD-EQUIS)] ${ }^{9}$ professional institutions have accredited Hong Kong's maritime programs, such as those offered by LMS, in achieving certain quality standards. These institutions offer constructive advice on how to articulate degree programs with a postgraduate study level in both local and overseas institutions.

Maritime education has flourished in Hong Kong in the past decade as evidenced by the increasing number of under- and postgraduate maritime programs offered by local tertiary institutions. However, the structures and characteristics of the demands for such programs remain under-researched. Through this study, a generalized trend regarding the profiles, motivation, and expectations of respective programs of students from maritime programs can be drawn and the similarities and differences in terms of professional experience, culture, gender, and competency among these students can be identified. Furthermore, we have offered ways to adopt effective planning and management of maritime program articulation and to sustain the development of Hong Kong as a world-class educational hub for maritime studies.

This paper is based on a single case study, i.e., Hong Kong, and is an initial attempt to apply a concept of professionalism in maritime education through an exploratory study. It should provide useful insight to professional bodies on how to improve the quality of these under- and postgraduate programs in the future. To increase the generalizability of our findings, we plan to conduct large-scale longitudinal studies on maritime education in other countries, for instance, a comparison of maritime programs offered in Hong Kong and those in other countries (e.g., Canada, Singapore, Vietnam, China, Thailand, Korea, etc.). A comparative study between Hong Kong and other Asian countries should be of great significance, as the findings will help to plot the general development of under- and postgraduate studies in maritime education. By doing so, we can create a strong platform in conducting further research on this important topic.

Acknowledgments The study was partly supported by the CPCE Research Funds (project account code: 4.8L.xx.EZ65). We thank the editor and anonymous reviewers for their constructive comments and advice. The usual disclaimers apply.

\section{References}

Armstrong JS, Overton TS (1977) Estimating nonresponse bias in mail surveys. J Mark Res 14(3):396-402 Barnett M, Gatfield D, Overgaard B, Pekcan C, Graveson A (2006) Barriers to progress or windows of opportunity? A study in career path mapping in the maritime industries. WMU J Marit Aff 5(2):127-142

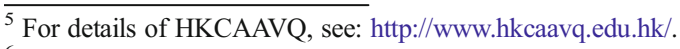

${ }^{6}$ N/SVQ is the Qualifications and Curriculum Authority of the UK, Scotland, Wales, Australia and New Zealand. For details of N/SVQ, see: http://www.sqa.org.uk/sqa/2.html.

${ }^{7}$ For details of AMBA, see: http://www.mbaworld.com/.

${ }^{8}$ For further details on AACSB, see: http://www.aacsb.edu/.

${ }^{9}$ For further details on EFMD-EQUIS, see: https://www.efmd.org/index.php/accreditation-main/equis.
} 
Becker G (1993) Human capital: a theoretical and empirical analysis, with special reference to education. The University of Chicago Press, Chicago

Bourner T, Bowden R, Laing S (2001) Professional doctorates in England. Stud High Educ 26(1):65-83

Carp D (2004) A network of excellence in maritime training. IAMU J 3(1):69-77

Cooper GT, Lewarn B, Otway NJ (2003) Trends in the quality assurance of maritime education: a case study from the Australian Maritime College. In: Proceedings of the 4th International Association of Maritime Universities General Assembly and Conference. Alexandria, Egypt, 26-30 September

Emad G, Roth WM (2008) Contradictions in the practices of training for and assessment of competency. Educ Train 50(3):260-272

Evangelista P, Morvillo A (1998) The role of training in developing entrepreneurship: the case of shipping in Italy. Marit Policy Manag 25(1):81-96

Fu X, Ng AKY, Lau YY (2010) The impacts of maritime piracy on global economic development: the case of Somalia. Marit Policy Manag 37(7):677-697

Gardner BM, Marlow PB, Naim MM, Nair R, Pettit SJ (2007) The policy implications of market failure for the land-based jobs market for British seafarers. Mar Policy 31(2):117-124

Grammenos CT (2002) The handbook of maritime economics and business. LLP, London

Hara K (2000) Present situation and perspective on research and education in the maritime society. IAMU J 1(1):5-9

Harlaftis G, Theotokas I (2004) European family firms in international business: British and Greek tramp shipping firms. Bus Hist 46(2):219-255

Heaver TD (2002) The evolving roles of shipping lines in international logistics. Int J Marit Econ 4:210-230

Hong Kong Maritime Department (2013) www.mardep.gov.hkAccessed November 21, 2013

Ircha MC (2006) Maritime education in cross-cultural settings. WMU J Marit Aff 5(1):37-59

Levinson M (2006) The box: how the shipping container made the world smaller and the world economy bigger. Princeton University Press, Princeton

Lewarn B (2002) Maritime education and training - the future is now! IAMU J 2(1):19-24

Malhorta MK, Grover V (1998) An assessment of survey research in POM: from constructs to theory. J Oper Manag 16(4):407-425

Mangan J, Gregory O, Lalwani C (2001) Education, training and the role of logistics managers in Ireland. Int J Log Res Appl 4(3):313-327

Moreby D (2004) Editorial. Marit Policy Manag 31(2):89-91

$\mathrm{Ng}$ AKY, Koo AC, Ho WCJ (2009) The motivations and added values of embarking on postgraduate professional education: evidences from the maritime industries. Trans Policy 16(5):251-258

$\mathrm{Ng}$ AKY, Koo AC, Pallis AA (2011) Professionalization of the shipping industry via postgraduate education. Ocean Coast Manag 54:364-373

Ng AKY, Liu JJ (2014) Port-focal logistics and global supply chains. Palgrave Macmillan, Basingstoke

Paine-Clemes B (2006) What is quality in a maritime education? IAMU J 4(2):23-30

Pettit SJ, Gardner BM, Marlow PB, Naim MM, Nair NR (2005) Ex-seafarers shore-based employment: the current UK situation. Marit Policy 29:521-531

Ruan W (2002) Meeting the requirement and development of maritime education and training. IAMU J 2(1):73-78

Sampson H (2004) Romantic rhetoric, revisionist reality: the effectiveness of regulation in maritime education and training. J Vocat Educ Train 56(2):245-268

Shah A, Treby E, May V, Walsh P (2007) Bridging the divide between academia and practitioners: training coastal zone managers. Ocean Coast Manag 50:859-871

Stopford M (2009) Maritime economics, 3rd edn. Routledge, London

Taussik J (1998) Interdisciplinary education: the masters programme in coastal and marine resource management at the University of Portsmouth, UK. Ocean Coast Manag 41:115-122

Theotokas I (2007) Top of world shipping: Greek shipping companies: organization and management. In: Pallis AA (ed) Maritime transport: the Greek paradigm. Elsevier, London, pp 63-93

UNCTAD (2012) Review of Maritime Transport 2012. United Nations Conference on Trade and Development (UNCTAD), United Nations, Geneva.

The 2013 Policy Address (2013) Seek change, maintain stability, serve the people with pragmatism. Government of the Hong Kong Special Administrative Region, Hong Kong

Transport and Housing Bureau (2012) Summary statistics on shipping industry of Hong Kong. Transport and Housing Bureau of the Government of the Hong Kong Special Administrative Region, Hong Kong

Zhu J (2006) Asia and IMO technical cooperation. Ocean Coast Manag 49(9-10):627-636 